\title{
Bjørnson og husmannskonen
}

I november 1906 fikk husmannskonen Marit Bøshaugen (1840-1906) påvist et inneklemt lyskebrokk. Etter at kommunelege Carl Mathiesen (1861-1952) forgjeves hadde forsøkt å reponere det, ble hun fraktet til amtssykehuset på Lillehammer der legene Jens Torp (1847-1916) og Jørgen Dobloug (1874-1957) opererte henne. Hun døde få timer etter operasjonen. I 1997 beskrev nevrolog Bjarne Ranheim (f. 1922) hva som skjedde (Tidsskr Nor Lægeforen 1997; 117: 4399-402).

\section{Bjørnstjerne Bjørnson, husmannskonen og legene}

En husmannskone som var en nær medhjelper av Bjørnstjerne Bjørnson (1832-1910) på Aulestad døde like før jul 1906 av et inneklemt brokk fordi hun ikke ble operert i tide. Bjørnson ble sint og foranstaltet gjennom artikler i pressen en straffesak mot den ansvarlige lege ved amtssykehuset. I saken opptrådte dikteren i vanlig intens stil, beskrevet av bl.a. en ung, dansk venn av familien, Nulle Finsen. Dikteren fremholdt bl.a. at pasientens sosiale status kunne ha hatt betydning for hennes skjebne, en fattig kone hadde samme krav på samvittighetsfull behandling som den rike eller fornemme. Saken ble behandlet i flere rettsmøter og det ble innhentet erklæring fra medisinsk sakkyndige. Saken ble imidlertid henlagt av Riksadvokaten. Sannsynligvis var dette den første straffesak mot en lege i Norge for inkompetanse og dårlig behandling av en pasient, som førte til døden. 